\title{
Reimagining Queer Film Festival as a Counterpublic Space. A Case Study of Turkey's Pink Life Queerfest
}

\begin{abstract}
This article discusses how film festivals provide a counterpublic space that goes beyond a cultural event for artistic exchanges, particularly in contexts where queer culture raises tensions both with political authorities and within society. They also serve as meeting points and safe spaces where LGBTIQ+ people gather to share experiences, emotions and ideas, to discuss critical issues such as gender politics, everyday violence, hate crimes, and to map out strategies for political action and resistance. However, queer film festivals often suffer from state-imposed restrictions, bans, prohibitions, and political surveillance and control mechanisms. Pink Life Queerfest (Pembe hayat kuirfest), Turkey's first and only LGBTIQ+ film festival, provides a platform for LGBTIQ+ people to address issues that are not usually discussed in (conventional) public spaces. This article, based on a case study of the Pink Life Queerfest, focuses primarily on exploring the political significance of film festivals at a local level, while, at the same time, reflecting upon a set of questions based on globalisation, politics of location, queer visibility and (counter) public space.
\end{abstract}

Keywords: counterpublic space, film festivals, queer, visibility, contemporary Turkey.

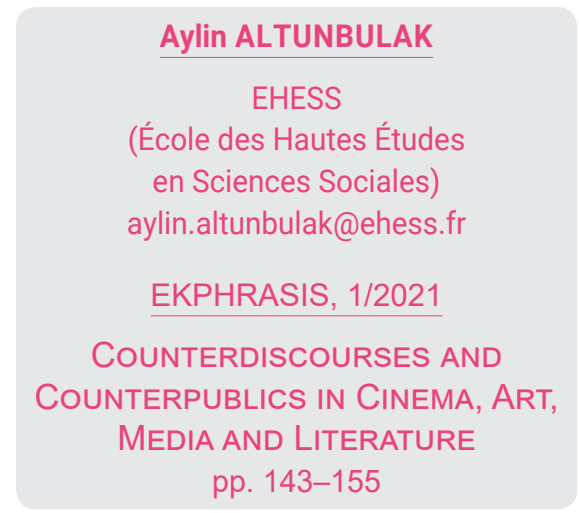

DOI: $10.24193 /$ ekphrasis. 25.10

Published First Online: June 21, 2021
Film festivals have traditionally been considered cultural activities and meeting places for a variety of actors with different agendas, such as artists, organisers, producers, intellectuals, audiences, volunteers and so on. They have also been seen as circuits of exclusive cultural environments that function as contact zones for the cinema industry and the distribution of art films. New 
approaches introduced to film studies since the 2000s have shown that film festivals are part of a complex and diversified global phenomenon that has enabled the development of independent cinema. Yet, access to film festivals for subaltern groups remains strongly affected by aesthetic standards (White 68), power relations around international political connections, unequal distribution of physical and material resources, systems of privilege and inequalities based on gender, race, sexual orientation. From the 1980s onwards, film festivals were reclaimed by feminists, LGBTIQ+ people, ethnic minorities and social movement activists, reimagined both within and across different social and historical contexts, and reinvented as spaces for political action. During this period, film festivals were converted into spaces that are not only meant for cultural and artistic exchanges, but also used as meeting points and safe spaces where audiences come together to share experiences, emotions and ideas, to challenge gender politics, everyday violence, hate crimes, and to develop strategies of political resistance.

The virtual film festival format brought by the Covid-19 pandemic has raised questions about the (physical) public space of film festivals and the "being-here-and-now"-ness of online film festivals during the pandemic (cf. Salti 2020). However, political scrutiny over online platforms also brings into question the issue of freedom of expression during an online event. In a context like Turkey's, who has a long history of internet regulation and censorship, the pandemic has provided the government with the proper justification to legitimise control over artistic production and cultural activities, surveillance of public spaces (both physical and virtual), increasing police violence, manipulation of the medias and denial of rights-based movements-especially trans, LGBTIQ+ and women's movements. In the meantime, the violence imposed on queer persons (kuir in Turkish) crystallized, as the political discourse got more and more homophobic and transphobic.

This period also provided an opportunity to explore the signification of (public) space for Turkey's first and only LGBTIQ+ film festival, Pink Life Queerfest (Queerfest from now on). With an emphasis on queer visibility and public space, as well as on freedom of expression and political intervention, this article aims to discuss the political and social importance that a queer film festival can acquire at a local level. Therefore, I suggest an analytic perspective that deals with film festival as a historically global—and mainly Western—phenomenon, in order to redefine it and rethink its implications for local—and non-Western-contexts. Based on this perspective, I analyse the political practices deployed during such a festival and the immediate legislative and political constraints that may arise in relation to it, as well as the counter-strategies invented on the spot in response to these constraints. 


\section{(Queer) film festival revisited}

Film festivals are primarily European phenomena. The first film festival was held in Venice, in 1932, as a part of the Venice Biennale. Cannes International Film Festival and the Berlinale were created in 1946 and 1951 respectively. They were initially interpreted as attempts to revive the European film industry which had suffered from two world wars and was challenged by the popular and quickly growing Hollywood cinema (de Valck 2007). Festivals gained popularity in Europe-and later all across the (Western) world-shortly after World War II, and played a key role in defining the arthouse cinema, and in reinventing and promoting the concept of auteur film.

Thomas Elsaesser, one of the first researchers to address the issue of film festivals within a conceptual framework, stressed that, as a result of their globalisation, film festivals have been important geopolitical and economic components of the audio-visual industry (2005), as they have created a special and significant culture and a community of arthouse and auteur film goers. Elsaesser categorises the film festival phenomenon as an international and closely interconnected circuit which "has globalised itself, and in the process, has created not only a self-sustaining, highly self-referential world for art cinema, the independent cinema and the documentary film, but [also] a sort of 'alternative' to the Hollywood studio system" (88).

Social movements of the 60 s and ${ }^{~} 70$ s, including civil rights movements, gay liberation movements, second wave feminism and student movements, prompted a shift in the content of film festivals and their role within the political field (Dawson and Loist 1). In conjunction with the evolution of social and rights-based movements, community-oriented festivals with a primary focus on identity politics and activism appeared in Europe and North America during the 70 s and '80s. The number of thematic and community-oriented festivals gradually increased, as feminist, black, people of colour, gay and lesbian, immigrant, and human rights-based groups started to organize dedicated events.

Along with the boom in politically involved film festivals, world's first queer/LGBTIQ+ festival took place in 1977, in San Francisco, under the name of Gay Film Festival of Super-8 Films Festival (Frameline Film Festival or San Francisco International LGBTQ+ Film Festival of today). The phenomenon of queer film festival has rapidly grown since the creation of Frameline and it "provided an opportunity for the enjoyment and popularisation of films on queer and LGBTI themes that may be otherwise difficult to access in the mainstream media” (Binnie and Klesse 2016). 


\section{Why is a "global queer" problematic?}

Aside from being platforms for the visibility of queer cinema, queer film festivals are also growing markets within an unevenly distributed international economy where Western queer cinema gets wider exposure and visibility (Rhyne 619). Film festival researcher Skadi Loist approaches the globalization of queer film festivals from a critical perspective, arguing that "queer globalisation and the global proliferation of LGBT/Q film festivals [c] ould be described as an expansion of Western models of LGBT/Q identities and politics” (116).

For a further explanation of what a film festival might represent from a local queer perspective, I find it useful and relevant to discuss globalisation within a critical framework, debating the hegemonic dimension of Western cultural influence. Recent works by nonWestern scholars on globalisation show it to be a rather homogenising concept which could be read as part of a "neocolonial movement of ideas and capital from West to nonWest” (Grewal and Kaplan 663). Queer communities, like others, inevitably engage in the global circulation of knowledge and cultural materials such as films, but this circulation still remains unbalanced and one-directional, given the fact that Western European and North American cultural materials are more likely to travel towards other regions (Ula 514-515). I therefore propose a local understanding of queer film festivals, rather than a global one. Drawing on Adrienne Rich's work on the politics of location, I argue that we should avoid the hegemonic positioning that seeks to universalise and homogenise queer experiences, constructing at the same time a somehow normative-hence limited and exclusionaryversion of queerness.

In her book Blood, Bread and Poetry, Adrienne Rich coins the term "politics of location" as a tool to distance her work from the hegemonic Western feminism, in order to theorise alternative subjectivities. Rich urges us to reconsider geographical space and to interpret it within a socio-political and historic framework, marked by displacement, erasure, or realignment in relation to power, either as an exercise of oppression or as resistance (212). Following Rich's point on alternative subjectivities, I stand against the generalising and globalising definitions of queerness and queer film festival, and call for a study of local subjectivities, to unravel and deconstruct hegemonic definitions based on European and/ or Western queer/LGBTIQ+ experiences. These definitions often tend to be insensitive to experiences of non-Western queer/LGBTIQ+ groups, as well as to their particular contexts. Stuart James Richards writes that "queer need not materialise in any specific form; rather, queer exists as a critical resistance to normality” (4). Building on Richards's point of view, I offer a plural and complex reading, rather than a singular version of queerness as it emerged in the West. 


\section{Conceptual framework and questions}

Previous studies on film festivals had considered them as networks of film circulation (Elsaesser 2005), sites of passage and forms of cultural performance (de Valck 2007), media events of collective performance (Dayan 2000), and important players in the articulation of film canons (Peirano and Vallejo 2017; Damiens 2020). They are also studied through the lenses of imagined communities (Iordanova and Cheung 2010) and (counter)public spaces (Fraser 1992; Wong 2011). However, early film festival studies focused mainly on major Western film festivals. As the film festival studies developed as a field of research on its own, especially after the creation of Film Festival Research Network ${ }^{1}$, studies about other, smaller and/or theme-oriented film festivals have multiplied and spread. More recent studies on film festivals "have focused on more peripheral geographical and linguistic areas including Africa, the Middle-East, Asia and Iberoamerica" (Peirano and Vallejo 4).

Queer film festivals have recently become an important focal point for several studies, both in social sciences and film studies. Antoine Damiens, in their first book titled $L G B T Q$ Film Festivals. Curating Queerness, stresses that "any consideration of non-Western festivals requires both deep and ethnographic knowledge of the country in which the event is organised and an understanding of foreign languages" (30). It also requires to be able to see how a film festival functions in these specific non-Western queer contexts, not only as an artistic event whose main purpose is to screen and discuss queer-themed films, but also as a safe space and a place for activism, where a collective political action of being present and taking up space is performed.

Queer film festivals can act as counterpublic spaces, when and where queer gatherings and visibility are challenged. They provide platforms for counterpublic and political discourses about problems, experiences, and claims of LGBTIQ+ communities. In their presentation at the "Queer Film Festivals as Activism" conference in 2016, Jon Binnie and Christian Klesse asked the following question: "How important are [queer] film festivals in articulating agendas around LGBTQ politics in different geographical and political contexts?" while discussing the role of queer film festivals in the formation of queer communities (Binnie and Kleese 2016). In order to answer Binnie and Klesse's question, we should consider that queer film festivals can be deployed as counterpublic spaces when discussions about LGBTIQ+ visibility and resistance are typically ignored from official public spaces, even silenced and criminalised by political authorities.

Reflecting on the (counter)public space of queer film festivals, I would also like to answer a few questions: What are the characteristics of the public space of a (queer) film festival? Do these characteristics differ from festival to festival? How can the concept of public spaceoriginally imagined as Western-bourgeois space for political discussions (Habermas 1978) be broken down and used from a local, queer, contemporary and non-Western perspective? 


\section{On (counter)public space}

According to Habermas, public space comes into existence when private individuals engage in practical discourse, thus creating a public body. The focus of these exchanges needs to be the interest of society as a whole, which he calls the general interest (14).

Jürgen Habermas's pioneering work on the genealogy and transformation of the public space during the modern era gave rise to theoretical discussions that have introduced various interpretations of the term. Michael Warner examines the plural meanings of both the public and the public space. Warner asserts that the public can be understood both as "a space of discourse" and "a concrete audience, a crowd witnessing itself in visible space" that is "bounded by [an] event or by the shared physical space" (50). In the context of queer film festivals, visibility is an important aspect of public space, an idea that will be further developed in the following paragraphs.

Feminist historian Joan B. Landes shows that the discursive field of public space, as conceptualised by Habermas, is fundamentally linked to "patriarchal politics." Through a set of contrasting binary social and political categories (like public and private, state and family, temporal and immutable, discourse and silence, universal and particular, culture and nature, rational and irrational, order and chaos, power and morality, justice and love, knowledge and superstition, city and country), it places women into one category and men into the other (25).

Debates led by feminists such as Nancy Fraser and Mary Ryan in the late 90 s and early 2000s regarding the structural transformation of the public space, called into question the general interest defined by Habermas. They argued that Habermas's perspective excluded gender politics and that this aspect had a great impact on the selection of issues considered worthy to be discussed and received into the public arena.

Based on her critical assessment of publicness as "a class and gender biased notion," Mary Ryan pointed out that the strictly and rigidly defined realm of the public spaceapprehended as a single and homogenous entity-has expanded through a process supported by social movements that have engaged and transformed the unanimity and passivity of public discourse (259). She stressed that, rather than a passive and limited public space, there is a variety of ways for accessing public life and a multiplicity of public arenas. Respectively, Nancy Fraser theorised what she defined as "parallel discursive arenas," where members of subordinated social groups, that have no direct access to the official public space, "invent and circulate counterdiscourses to formulate oppositional interpretations of their identities, interests, and needs" (123). According to the feminist accounts mentioned above, journals, books, bookstores, conferences, film festivals, film and video distribution contribute to the formation of counterdiscourses, normally marginalized or excluded from the realm of (conventional) public space. Feminist approaches to public sphere studies can thus provide 
the theoretical basis for the analysis of (counter)public spaces and couterdiscourses in relation to queer film festivals.

American theorist Kimberlé Williams Crenshaw has also shown that the "dominant liberal discourse" often treats class, race, gender, and other categories of identity "as inherently negative analytical frameworks invested by social power to exclude or marginalise those who are different" (64). Crenshaw's account is crucial to understanding that what Habermas originally defined as "general interest" is not uniquely gender-blind, but that it tends to ignore the overlapping and interconnected nature of social categorizations like race, class, and gender within the systems of discrimination and privilege. Thus, the question of visibility is particularly important in revealing and discussing the availability of public space for subaltern groups, or for "those who are different," as Crenshaw stresses.

In the next part, I'll discuss the politics of film festival organising in Turkey, focusing on the (non)accessibility imposed by government interventions, as well as the journey of Queerfest, highlighting both the visibility of queer subjects in the public sphere, as well as the tensions that such visibility creates in political realm.

\section{Queerfest: A decade of festival activism}

Film festival organising in Turkey has such dynamics that political decisions may influence the management, jury and film selection processes, and other festival activities, thus causing tensions in terms of the politics and economics of film festivals (Akser 141-146). A large part of film festivals in Turkey are managed and financed by municipal authorities. Yet, Turkey's most well-known Istanbul International Film Festival is organised by Istanbul Culture and Arts Foundation (IKSV), which is funded by a private corporation called Eczacıbaşı Holding. Other film festivals which are not funded by municipalities and other local political authorities are mainly community-based film festivals like Queerfest, and are oftentimes attacked by the Turkish government. These festivals are mainly organised by small teams within or with the help of independent non-profit organisations, communitybased associations and are co-funded by a variety of sponsors, such as embassies, international NGOs, cultural institutions, museums, etc. They provide counterpublic spaces where political activism intertwines with festival programming, film screenings, debates, Q\&A sessions, talks, exhibitions and other festival related events.

Queerfest is an international film festival organised by a small and close-knit team of four to five people. Since its foundation in 2011, in Turkey's capital Ankara, Queerfest has been held annually. It stayed in Ankara for its first three years, where it contributed to the revival of queer cultural and artistic activities in the city, whilst also creating an alternative to Istanbul, typically considered Turkey's epicentre for art and cultural events, both for queers 
and in general. From its fourth edition on, Queerfest was held simultaneously in several cities, other than Ankara, such as Istanbul, and abroad, in Amsterdam and in Berlin, where Queerfest collaborated with LGBTIQ+ diasporas. Besides, the festival has been in touch with LGBTIQ+ organisations and associations from smaller cities; for instance Mersin, which is a historically significant place for the trans community, and in Denizli, which has turned into a transit and resettlement zone for LGBTIQ+ immigrants coming from Iran, Iraq and Afghanistan.

In addition to screening films by queer artists, Queerfest aims to "highlight key topics of concern within the LGBTIQ+ community, like discrimination and everyday violence," and to "create a safe space where queer theory and art can be expressed and discussed openly and freely" ("Biz Kimiz?”). Queerfest also commits to creating a variety of events ranging from Q\&A sessions with filmmakers, exhibitions, and parties to conferences, workshops and roundtables discussing both general and immediate problems of the LGBTIQ+ community in Turkey and trying to come up with solutions to these problems.

As other queer visibility and counterpublic spaces in Turkey, Queerfest has had to deal with political pression, government's surveillance strategies, threats, bans and restrictions. During this battle, Queerfest has become the emblematic queer event in Turkey, but also the biggest target of government bans. However, to quote the Queerfest team, despite all obstacles, Queerfest found solutions "by creating alternative spaces, and leaking through every fracture" (Akbulut, 2019).

\section{The problem of being queer and being here}

Queer and trans existences and visibilities have been ignored for a long time ${ }^{2}$ by the Turkish government. Today, the government is engaged in an active battle against queer visibility in public spaces. Carrying the rainbow flag in public may lead to being arrested by the police. Using the words "queer" and "LGBTIQ+" during public events and showing queer characters in movies and television may soon be criminalised. The state of emergency declared after the $15^{\text {th }}$ of July 2016 failed coup unquestionably provided legislative grounds to restrict the freedom of expression and the freedom of assembly, both for queers and in general, during the two years of state of emergency and the subsequent period. I suggest here to look back at important moments throughout the long history of state violence against queer visibility in Turkey, especially during the period that led to the state of emergency and afterwards.

$23^{\text {rd }}$ LGBTIQ+ and trans pride marches were banned from Istanbul's emblematic Taksim square in June 2015 on the grounds of Ramadan month and public sensibility, and from the entire city in 2016 due to the state of emergency. The bans on LGBTIQ+ and trans pride marches in Istanbul were followed by similar bans in some other big cities, such as Izmir, 
Antalya and Mersin, in June 2019. On the $18^{\text {th }}$ of November 2017, the city of Ankara, Turkey's capital city and Queerfest's home town, banned all LGBTIQ+ events completely and indefinitely for the first time in history. The reasons invoked by the authorities were the protection of social sensitivity and the upholding of moral standards in society. This decision, which violates the constitutional rights of LGBTIQ+ people, was subsequently justified on the basis of state of emergency laws. The day before the complete ban, the city first announced on its official website the ban of German LGBTI Film Days, a series of film screenings organised by Queerfest in collaboration with the German Embassy, then the ban of all LGBTIQ+ events the next day. It was very clear that the ban specifically targeted Queerfest. Queerfest hence had to transfer its events outside Ankara and planned a short film screening in Istanbul. A week after the ban in Ankara, Istanbul's Beyoğlu district postponed, then banned Queerfest's Queer Shorts film screening, alleging that this event could provoke the "reiteration of 2013 Gezi park protests," "an armed conflict," and even "a civil war," as reads the letter addressed to the event venue by the district governor himself ("Beyoğlu Kaymakamlı̆ğ”).

After the bans, the LGBTIQ+ community fought back with the hashtag \#LGBTIFilmleriYasaklanamaz (\#LGBTIFilmsCannotBeBanned) on social media platforms and Queerfest shared previous festival films on its Facebook and Vimeo pages. It then prompted the launch of Pink Life YouTube channel featuring collectively produced content. Nevertheless, the seventh Queerfest was held in Istanbul between 26-28 January 2018 without any political intervention. Attorneys of Pink Life LGBTT Solidarity Association carried Ankara city's ban on LGBTIQ+ events to the court. After a long battle with the capital's administrative court and eventually with the Supreme Court, the ban was lifted during the first wave of the pandemic, on $23^{\text {rd }}$ of March 2020.

During the first wave of Covid-19, which happened a few months after the ninth Queerfest, the festival organised a series of online screenings called Queerfest Quarantine (Kuirfest karantina). As the tenth edition of Queerfest approaches, festival organisers have decided to postpone this year's events until September of 2021, rather than transforming the tenth edition in an online festival; a decision which I believe reflects the importance and the political significance of being physically on the spot, being visible and claiming an actual physical space.

Returning to the question of the pandemic and virtual public spaces mentioned in the introduction, Turkish government's widespread surveillance and control mechanisms did not leave room for open political discussion on online platforms. In Turkey's history of internet regularisation and censorship, online platforms like Twitter, YouTube, Wikipedia, and local online press have been repeatedly restricted and/or blocked by the government, especially when they served as crucial tools of communication and resistance during protests and social movements, generally lacking press coverage due to mainstream medias being manipulated and controlled. It is also a recurring pattern for politicians to criminalise people or label them 
as terrorists by accusing them of terrorist propaganda, crimes against national security or insulting of public officials and elected politicians, based on their activity on social medias. Therefore, Queerfest's decision to postpone the festival is understandable, as the main focus of the festival is to create an open and safe space for LGBTIQ+ people, rather than show films and build networks of film distribution.

Queerfest launched its tenth-year events with an online conference called "Queerentalize Film Cultures," which took place via Zoom on the $27^{\text {th }}$ and $28^{\text {th }}$ of February. However, the festival itself will be held physically, both in Ankara and Istanbul between $23^{\text {rd }}$ of September and the $3^{\text {rd }}$ of October 2021. Organising a physical gathering during the pandemic is a concern for the festival team, although they confirm that they are trying to adapt as best they can to the current circumstances by taking extra precautions and prioritising open-air venues for the upcoming festival, while also pointing out that online gatherings are "simply not enough" and that the atmosphere and sense of community is much more different in the physical space of the festival. ${ }^{3}$ Taking into account the political scrutiny over online spaces and the lifting of the ban on LGBTIQ+ events after two and a half years of legal battle, the fact that the tenth Queerfest will take place physically-especially in Ankara where the ban was declared-has another meaning, a quite political one.

\section{Conclusion}

In contemporary Turkey, creating a space for queer visibility through a film festival is particularly challenging. The denial of LGBTIQ+ rights, the bans on queer events and the oppression of LGBTIQ+ and trans movements create an atmosphere of political violence that targets LGBTIQ+ subjects. In such a political context, Queerfest represents both a site for discussions about possible resistance strategies to subvert existing political repression, and a counterpublic space that aims to challenge the political agenda by introducing queer subjects and subjectivities that are not usually addressed, nor accepted in the official public space.

As Judith Butler asserts, the collective act of bodies assembling in public spaces, whether it be on the street, in a public square or other spaces (including virtual ones), puts a plural and performative right to appear into practice, a right which establishes and integrates those bodies, hence their existence and visibility, lives and experiences, questions and claims into the political ground (11). Being on the spot, being visible and taking up space indicates therefore a proper political action. In this case, film festival transcends the limits of being a space for cultural, artistic and/or community-based exchanges. Being collectively present in the counterpublic space of the queer film festival becomes a politically significant quest for recognition, visibility and political change. 
During a personal interview, when asked about the collective experience of public space during the film festival, a former Queerfest coordinator and team member noted that attending the Queerfest was, for both audiences and organisers, "never only about the films screened" and that the festival itself was "a space for resistance" (Özban 2021). Film studies researcher Cindy Hing-Yuk Wong argues that queer/LGBTIQ+ film festivals embody visible presence of queer audiences and their issues, and that they are "of, by and for queer people, a place of presence" (181-182). Based on Wong's point-and taking it further-I suggest that queer presence and visibility acquire a political significance in specific sociopolitical contexts, especially where queer visibility in public spaces is challenged by political discourses, government policies and state violence. The queer film festival then transforms into a counterpublic space for discussions that are ignored and silenced in the official public sphere. The counterpublic spaces established within film festivals constitute a key space of activism (Binnie and Klesse 65) and a place for the embodied practice of expressive political action; a space where LGBTIQ+ people gather and publicly demonstrate their existences as a political statement.

\section{End Notes}

1. Film Festival Research Network is a network of scholars working on film festival studies, founded in 2008 by Marijke de Valck and Skadi Loist, for the purpose of building a connection around film festivals as a research subject. It is also meant to compile a corpus of works conducted in the field. More information on Film Festival Research Network is available on http://www. filmfestivalresearch.org.

2. On 3 February 2021, Turkish president completely denied the existence of LGBTIQ+, while commenting on the ongoing student protests. He stated that there was "no such thing as LGBT people in our country, which is only ruled by moral and national values." Both Erdogan and other politicians then labelled LGBTIQ+ youth as "immoral," "deviant" and even "terrorist" on multiple occasions.

3. From personal notes taken during Queerentalize Film Cultures conference, 27 February 2021.

\section{Works Cited}

AKBULUT, Kültigin Kağan. "Yasaklara karşı alternatif direniş yöntemleri oluşturuyoruz” ("We create alternative methods of resistance against the bans"), susma24.com, $27^{\text {th }}$ of June 2019: https://susma24.com/yasaklara-karsi-alternatif-direnis-yontemleri-olusturuyoruz/. Accessed on February 14, 2021.

AKSER, Murat. "Turkish Film Festivals: Political Populism, Rival Programming and Imploding Activities," in Iordanova D. and S. Van de Peer (eds.), Film Festival Yearbook 6: Film Festivals and The Middle East. St Andrews Film Studies Publishing, 2014, pp. 141-155. 
ASKRI, Weema, GÖKO, Esma, MUNIR, Saadat, SHAFIE, Ghadir, panelists. Panel discussion on Queer Film Festivals. Queerentalize Film Festivals Conference, 27-28 February 2021, Zoom (online).

"Beyoğlu Kaymakamlığı yasağı Anayasa Mahkemesi’nde” ("Beyoğlu District Governor's ban in the Supreme Court”), pembehayatkuirfest.org, Pembe Hayat Kuir Fest, https://www.pembeh ayatkuirfest.org/beyoglu-kaymakamligi-yasagi-anayasa-mahkemesi-nde-a8. Accessed on February $14,2021$.

BINNIE, Jon and Christian Klesse. "Comparative Queer Methodologies and Queer Film Festival Research.” Queer Film Festivals as Activism: An International Symposium, 5-6 February 2016, Manchester Metropolitan University. Address: All Saints, Manchester, UK.

---. "Comparative queer methodologies and queer film festival research," Studies in European Cinema, 15 (1), 2018, pp. 55-71.

"Biz Kimiz? (Who are we?)”, pembehayatkuirfest.org, Pembe Hayat Kuir Fest, https://www. pembehayatkuirfest.org/index.php. Accessed on February 16, 2021.

BUTLER, Judith. Notes Toward a Performative Theory of Assembly. Harvard University Press, 2015.

CRENSHAW, Kimberlé Williams. "Cartographies des marges: intersectionnalité, politique de l'identité et violences contre les femmes de couleur," Cahiers du Genre, 39 (2), 2005, pp. 51-82.

DAMIENS, Antoine. LGBTQ Film Festivals. Curating Queerness. Amsterdam University Press, 2020.

DAWSON, Leanne, and Skadi Loist. "Queer/ing film festivals: history, theory, impact," Studies in European Cinema, vol. 15, no. 1, 2018, pp. 1-24.

DAYAN, Daniel. "Looking for Sundance: The Social Construction of a Film Festival," in Bondebjerg, Ib (ed.), Moving Images, Culture and the Mind, University of Luton Press, 2000, pp. 43-52.

DE VALCK, Marijke. Film Festivals: From European Geopolitics to Global Cinephilia. Amsterdam University Press, 2007.

ELSAESSER, Thomas. European Cinema Face to Face with Hollywood. Amsterdam University Press, 2005.

FRASER, Nancy. "Rethinking the Public Sphere: A Contribution to the Critique of Actually Existing Democracy," in Calhoun Craig (ed.), Habermas and the Public Sphere, MIT Press, 1992, pp. 109-142.

GREWAL, Inderpal and Caren Kaplan. "Global Identities: Theorizing Transnational Studies of Sexuality,” GLQ: A Journal of Lesbian and Gay Studies, no. 7, 2001, pp. 663-679.

HABERMAS, Jürgen. L'espace public : Archéologie de la publicité comme dimension constitutive de la société bourgeoise. Marc B. de Launay (trad.), Payot, 1978.

IORDANOVA, Dina, and Ruby Cheung. "Introduction," in Iordanova, Dina and Ruby Cheung (eds.), Film Festival Yearbook 2: Film Festivals and Imagined Communities, St. Andrews Film Studies, 2010, pp. 1-10.

LANDES, Joan B. Women and the Public Sphere in the Age of the French Revolution, New York: Cornell University Press, 1988.

ÖZBAN, Esra. Personal interview. 16 March, 2021. 
PEIRANO, Maria Paz and Aida Vallejo. "Introduction. Film Festivals and Anthropology," in Peirano, Maria Paz and Aida Vallejo, Film Festivals and Anthropology, Cambridge Scholars Publishing, 2017.

RHYNE, Ragan. "The Global Economy of Gay and Lesbian Film Festivals.” GLQ: A Journal of Lesbian and Gay Studies, 12, 2006, pp. 617-619.

RICH, Adrienne. "Notes on a Politics of Location." Blood, Bread, and Poetry. Norton, 1989, pp. 210-31.

RICHARDS, Stuart James. The Queer Film Festival. Popcorn and politics, Palgrave Macmillan, 2016.

SALTI, Rasha. "Do Not Go Gentle into That Good Night: Film Festivals, Pandemic, Aftermath," Film Quarterly, 74.1, 2020, pp. 88-96.

RYAN, Mary. P. “Gender and Public Access: Women's Politics in Nineteenth Century America,” in Calhoun, Craig (ed.) Habermas and the public sphere, MIT Press, 1992, pp. 259-288.

SKADI, Loist. "The Queer Film Festival Phenomenon in a Global Historical Perspective," in Fléchet, Anaïs and Pascale Goetschel, Patricia Hidiroglou, Sophie Jacotot, Caroline Moine, Julie Verlaine (eds.), Une histoire des festivals, XXe-XXIe siècles, Publications de la Sorbonne, 2013. pp. 109-121.

ULA, Duygu. "Toward a Local Queer Aesthetic. Nilbar Gures's Photopraphy and Female Homoerotic Intimacy," GLQ: A Journal of Lesbian and Gay Studies, 25.4, 2019, pp. 513-543.

WARNER, Michael. "Publics and Counterpublics”, Public Culture, January 2002, 14.1, pp. 49-90.

WHITE, Patricia. Women's Cinema, World Cinema. Projecting Contemporary Feminisms. Duke University Press, 2015.

WONG, Cindy Hing-Yuk. Film Festivals. Culture, People, and Power on the Global Screen. Rutgers University Press, 2011. 